\title{
An Empirical Study of the Socio-Economic Effects of Supporting Flag Carriers: The Case of the Caribbean community (Caricom)
}

\author{
David Warnock-Smith ${ }^{1, a, *}$ and Peter Morrell ${ }^{1, b}$ \\ ${ }^{1}$ Department of Air Transport, Building 115, Cranfield University, Cranfield, Bedfordshire \\ MK43 OAL, England
}

\begin{abstract}
Access to efficient and affordable air transport services is indispensable to economic communities made up of dispersed islands. It is often claimed that the contribution of the sector would be greatly debilitated however without the presence of national or regional flag carriers. A multi-method, net economic impact assessment indicates that the direct impact of the sector in terms of employment and contribution to GDP increases with the presence of local flag carriers. Yet the more significant indirect macroeconomic impacts of the sector, in terms of consumer surpluses, incoming visitor expenditures and business investments are all found to be better facilitated by foreign carriers. The magnitude of impact was primarily determined by exogenous factors namely, relative size of a state's real GDP, relative contribution of other sectors, relative level of trade dependency and relative level of socioeconomic development, with larger impacts being noted in smaller, poorly diversified islands, chiefly dependent on sustaining a net surplus of air transport facilitated incoming visitor expenditure. Improvements to the performance of the sector are aligned with increases in aggregate incoming demand, thus far better supplied by cheaper, more frequent foreign carrier services providing a higher quality of service to and from the main source markets. Positive direct impact levels in those states with home carriers, low levels of service importing and an inverse relationship between local carrier absence and levels of connectivity show local carriers also play a significant facilitating role in the region's air transport sector.
\end{abstract}

Keywords: National carriers, foreign carriers, macroeconomic impact, island states.

\footnotetext{
a David Warnock-Smith is a Lecturer in Air Transport at the University of Huddersfield's Department of Transport and Logistics. He completed his PhD at Cranfield University's renowned Department of Air Transport, evaluating the macroeconomic effects of partial air policy reform in Caribbean markets.

${ }^{*}$ Corresponding author. E-mail: d.warnock-smith@cranfield.ac.uk, phone: +44(0) 1234 754236, Fax: $+44(0) 1234752207$

${ }^{b}$ Peter Morrell holds a chair in air transport economics and finance at Cranfield University. He graduated in economics from Cambridge University and subsequently gained a Masters in air transportation from the Massachusetts Institute of Technology. He completed his doctorate at Cranfield University on airline capital productivity.
} 


\section{INTRODUCTI ON AND BACKGROUND TO CASE-STUDY REGI ON}

The principal benefit of air transport services operating in disparate island communities can be summarized by the fact that they provide a vital social and economic link between peoples, countries and cultures. The air transport sector, not only impacts an economy in terms of its direct, indirect and induced contribution to employment, but also serves as a strategic catalyst, enhancing business efficiency and productivity by providing easier access to suppliers and customers (Airports Council International, 2004). By opening up new markets for international travel, the sector is also considered to be a major driver for the tourism industry.

It has been noted that in regions where the provision of efficient air services are largely dependent upon the success of one national carrier, a sudden loss of direct services can have serious implications for a regional economy. This was found to be the case in a study which looked at the effects of the closure of Swissair on Zurich Airport as well as upon the region which it supports (Airports Council International, 2004). The direct, measurable impact of such a reduction in air services is not so severe if there are low barriers to foreign carrier entry and a low national carrier hub concentration ratio. In these instances, a continuation of services would ensure that an airport's employment density remained high and its direct impact buoyant.

It is also believed that accommodating a national carrier creates significant multiplier benefits within a national economy. However this hypothesis assumes that firstly there is no idle capacity within an economy. If there is, as is invariably the case, then increases in national output can just as easily be claimed by other public/private organisations. Second, it is assumed that the sector's direct output and employment would not be as efficiently provided by the private sector, by foreign carriers or a combination of both (Barrett, 2006). In fact, the general net social benefit sought by a protective air policy is rarely realised in reality. In 1969, a cost-benefit analysis conducted on behalf of I reland's national airline Aer Lingus, proposed a true social rate of return on capital employed of between $11 \%$ and $26 \%$ (O'Donoghue, 1969) when benefits such as foreign exchange earnings, tourism promotion and additional income expenditure are included. These benefits are refuted and said to be overstated however by Barrett (2006) who contends that rather than having a positive social effect, protectionist policies actually lead to inefficiencies, high access costs and a loss of international competitiveness. 
The method of 'shadow pricing' in order to take into account the indirect value of a national carrier can therefore be misleading. The true value creation of a national carrier can be better estimated within the context of a holistic impact study of a nation's or region's air transport sector. Net economic contribution according to Pearce (2005) means total value created by the sector in excess of the cost. For customers this means value in excess of ticket costs, for producers this means revenue in excess of operating costs and for an economy as a whole it means impact on GDP from boost to productivity, foreign exchange earnings and business investment in excess of congestion and the next best use of capital and labour. Thus the direct and multiplier impacts of national carriers can be better estimated within the context of its relative role within the wider mix of producers and suppliers involved in the provision of air transport services.

Table 1 reflects the consistently poor financial performance that has plagued the Caricom region's protected home carriers since the 1970s. Although these losses have frequently been linked to the industry's facilitating role for regional integration, a lower rate of decline in average real yields on Intra-Caribbean markets points towards pent up cost side inefficiencies when compared to other regional air markets (See Figure 1). Except for the years 1997 and 1998, country-pairs on which foreign carriers had the lion's share of capacity $^{1}$ showed constant year on year reductions in real yield between 1996 and 2004.

Conversely, on intra-Caribbean country-pairs, where regional flag carriers enjoy a greater market share, average real yields have failed to decline so markedly. In fact from 2002 to 2004 real intra-Caribbean yields actually increased ${ }^{2}$.

Table 1: Recent financial data for the main Caribbean based air carriers

\begin{tabular}{cccc}
\hline Net profit (loss) US\$mn & BWIA (BW) & LIAT (LI) & Air Jamaica (J M) \\
\hline 1976 & $(2)$ & $(2)$ & $(1)$ \\
2004 & $(15)$ & $(11)$ & $(99)$ \\
2005 & $(27)$ & $(8)$ & $(131)$ \\
2006 & $(50)$ & $(20)$ & $(128)$
\end{tabular}

Sources. World Bank document (2006), ICAO data for 1976 financial information, airline annual reports

\footnotetext{
${ }^{1}$ Average foreign carrier capacity shares between 1996 and 2004 were $4.4 \%, 66.4 \%$ and $59.6 \%$ for Intra-Caribbean, EuropeCaribbean and North America-Caribbean markets respectively (OAG, 2008).

${ }^{2}$ Absolute differences in yield relating to average sector distance and aircraft size are isolated from possible cost side affects by using percentage rates of change as shown in Figure 1.
} 
Figure 1: Average percentage change in real yields for selected intra-Caribbean, North America-Caribbean, and Europe Caribbean markets 1996-2004

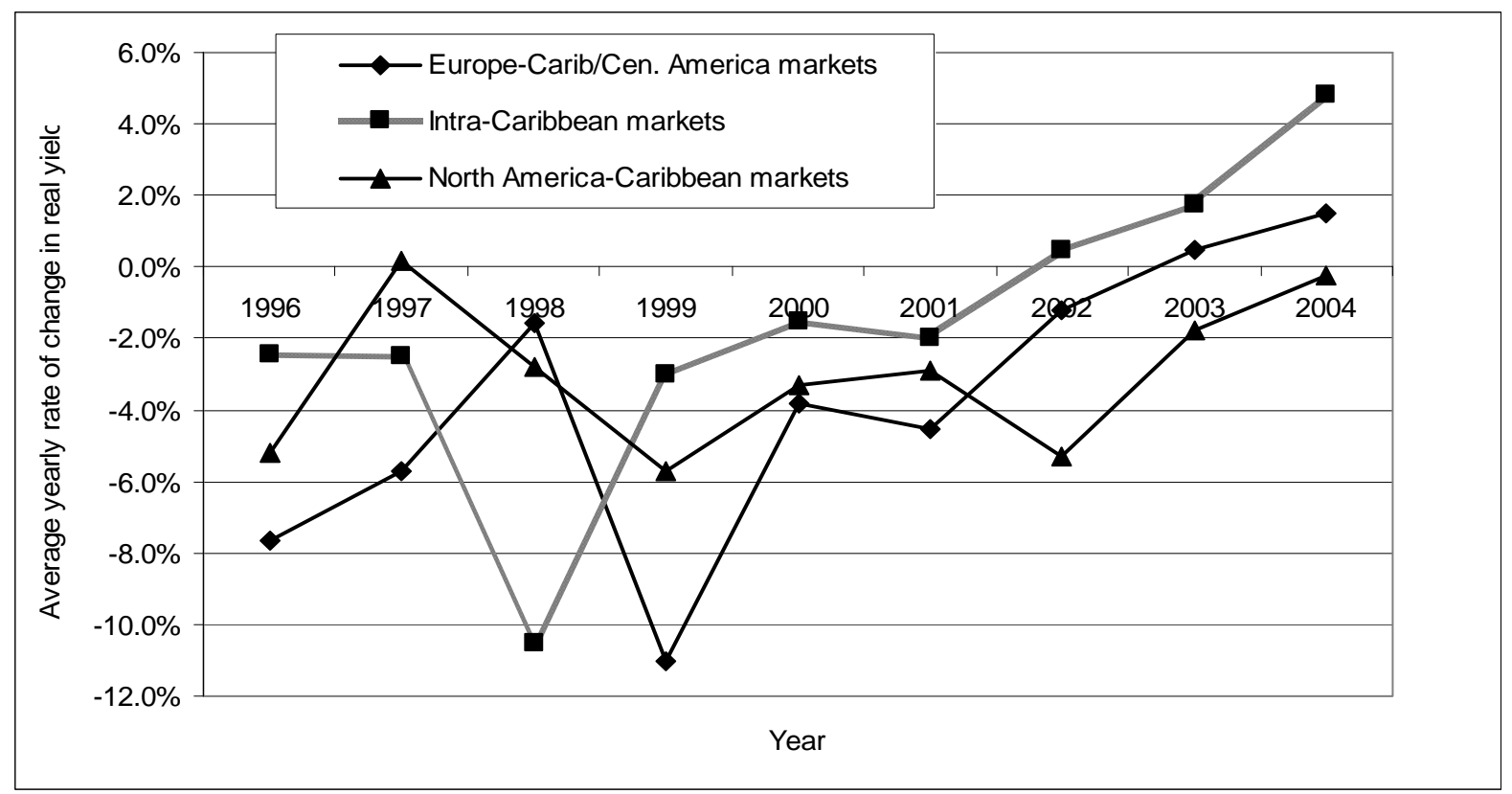

Source: ICAO Air Transport Bureau (2005)

It would therefore appear that loss-making local carriers are not creating as much consumer welfare in the form of lower airfares as on routes with a higher concentration of foreign carriers, something which clearly needs to be tested further when attempting to estimate the catalytic contribution of the sector ${ }^{3}$.

Pagliari (2003), in an air transport study of the Scottish Highlands and Islands, noted that in order to maintain social cohesion in displaced island communities, the high costs associated with operating air services combined with the need to maintain air transport infrastructure even for the smallest populations normally requires a predetermined level of governmental subsidy. But instead of adopting a comprehensive and well organised Essential Air Service (EAS) type system of subsidies as organised in the United States or a system of route tendering and franchising as witnessed in Europe, local carriers in the Caricom region have periodically received large cash injections on an ad-hoc basis from interested governments (see Table 2) without any predetermination of required service levels or timetables for reducing subsidy levels in line with forecasted increases in route densities.

\footnotetext{
${ }^{3}$ In this example, additional consumer surplus is classified as a catalytic impact given that foregone disposable income spent on airfares is no longer available for expenditure in other areas of an economy.
} 
Table 2: Five year subsidy assigned to the Caricom region's major flag carriers 2002-2006 (US\$mn)

\begin{tabular}{|c|c|c|c|c|}
\hline Carrier & BahamasAir (UP) & BWIA (BW) & LIAT (LI) & Air Jamaica (JM) \\
\hline 2002 & 12.0 & 13.0 & 14.5 & 70.0 \\
\hline 2003 & 0.0 & 0.0 & 14.5 & 30.0 \\
\hline 2004 & 0.0 & 0.0 & 14.5 & 30.0 \\
\hline 2005 & 0.0 & 0.0 & 8.0 & 32.5 \\
\hline 2006 & 28.5 & 250.0 & 8.0 & 32.5 \\
\hline 5 year totals & 40.5 & 263.0 & 59.5 & 195.0 \\
\hline
\end{tabular}

Sources: World Bank document (2006), CRSTDP (2007), Caribbean Development Bank (2007), airline data

Notes: LIAT figures do not represent actual yearly injections but an average of the cumulative totals indicated in the Trinidad Guardian (2006) 2002-2004 and World Bank study (2006) 2005-2006. The unusually high injection for BWIA in 2006 was related to its closure and the associated writing off of its long term debts in readiness for the creation of new carrier Caribbean Airways in January 2007

In macroeconomic terms, direct subsidy forms a negative tax on production and thus acts as a moderating force on the sector's direct contribution to GDP. It is one of the aims of this study to estimate the extent to which, in a sample of Caricom states, the sector's direct impact has been suppressed by the continued subsidy of local carriers by comparing states that have not been subjected to this financial burden to states that have. Assuming it is the aim of government to maximise, ceteris paribus, the macroeconomic contribution of the sector, it is important to find ways to reduce subsidy whilst ensuring service and efficiency levels on a route level are not compromised. Any commercially viable routes are then automatically served by a combination of local and foreign operators.

The concept of national loyalty as a social benefit must also be considered especially in the case of small island states that have, in the main, only recently inherited sovereignty from their old colonial powers. In a study of 427 Canadian travellers Bruning (1997) discovers that although a certain amount of national loyalty is present, if continued operations result in service or price disadvantages, consumers will tend to switch to foreign carriers. Thus, as well as dealing further with the quantitative aspects as previously mentioned, a further intention of this study is to assess the possible influence of a passenger's country-of-origin on choice of carrier in the Caricom region with reference to the findings of Bruning (1997).

\section{PREVI OUS I MPACT ASSESSMENT WORK}

Raguraman (1997) contends that tourism impact studies must be extended to include outbound local tourists and the means of transport. Impact studies that account for expenditure outflows are typically referred to as net impact assessments. In air transport 
literature this net impact forms part of a bundle of contributions arbitrarily termed catalytic impact.

It is important for tourism intensive economies to note however that international airlines also generate expenditures in their own right, which can represent sizeable injections into the local economy (Raguraman, 1997). But it is also of equal importance to account for the importation of airlines services and the repatriation of profits. As most international air services are provided on a third and fourth freedom basis (Doganis, 2003), capacity increases available for foreign tourists would inevitably translate into equal capacity increases for local populations wishing to take expenditure out of an economy ${ }^{4}$.

This was also one of the main criticisms of the scope of a recent impact study of national flag carrier, Air Jamaica on the national economy of Jamaica (Clarke et al, 2005). MadjdSadjadi (2005) claims that, in the paper, there is no accounting for the fact that passengers travelling on Air Jamaica are often originating from Jamaica. This leads to unrealistic assumptions of the true facilitating role of an airline to a nation's GDP.

The social benefit derived from increased travel opportunities for local populations is not considered either by the study itself or by Madjd-Sadjadi's criticism. In a global study, the Air Transport Action Group (2005) state that this perceived increase in quality of life can in fact encourage locals to remain in their home countries and improve their labour productivity as a result of the greater work/life balance afforded by access to international travel. The Madjd-Sadjadi (2005) study does allude to the fact that local employment will often rise as a result of increased usership no matter if passengers originate in the host country or not. Although it is difficult to qualitatively account for the first consideration, both are important omissions which need to be assessed more thoroughly in a more extensive impact assessment.

In a report commissioned by the Civil Aviation Authority (1994), which assessed the economic impact of new, foreign carrier, long-haul routes to and from the UK, it was found that, despite the fact UK airlines would experience a revenue loss of $£ 5.5$ million per year per new route, and a high proportion of traffic would have been UK originating leisure traffic, it was still likely that the overall effect on the UK was an additional gross expenditure

\footnotetext{
${ }^{4}$ Since the introduction of seat only sales, charter carriers operating into the region have also had the ability to tap into local markets.
} 
of $\mathbf{f 1 . 5}$ million. This translated into an estimated 33 extra jobs per year in the aviation/tourism sector. It would follow that in Caribbean nations with generally low expenditure outflows and poorly performing local carriers, the introduction of new foreign services may result in economic benefits of a greater magnitude than those found in the CAA study. This is especially so in cases where foreign carrier surpluses are passed on to the consumer in the form of lower fares, where new services lead to greater tourism inflows and where improved levels of customer service are introduced onto a network. National earnings from foreign carriers in the form of landing/parking fees, fiscal revenues, commission to local travel agents and capital investment income generation also need to be considered in markets where protectionist measures are stifling the provision of services by foreign operators.

Montalvo (1998) introduces the concept of 'transferability' which also needs to be considered in any net impact assessment. In the absence of a general equilibrium analysis it is difficult to quantify the amount of job and income substitution that would take place in the absence of a national carrier. As air transport and travel are interdependent however, tourism dependent, poorly diversified economies would clearly suffer if the absence of a national carrier would lead to an overall decrease in output. By extension, it is also reasonable to assume that a decrease in total air capacity regardless of whether it was provided by a domiciled carrier or not could lead to displaced employment when this employment cannot be easily incorporated into other sectors.

\section{RESEARCH PLAN}

Using a representative sample of seven Caricom states, it was possible to estimate the disaggregated net economic impact of the industry for the year 2006 broken down by island states where national carriers were present as opposed to markets where they were not. There are clearly many different facets related to economic impact which use a number of distinct measures. For the purposes of this study, the widely accepted ICAO (2005) definition of the breakdown of impacts was used as a basis by which to ensure a wider range of contributions were considered (See Table 3). 
Table 3: ICAO impact classification

\begin{tabular}{|c|c|c|}
\hline Classification & Players & Activities \\
\hline Direct & $\begin{array}{l}\text { Airport firms and } \\
\text { organisation based on } \\
\text { site }\end{array}$ & $\begin{array}{l}\text {-Involved directly in the delivery of air transport services to end users } \\
\text { and to industries } \\
\text {-Order intermediate services and products from various suppliers } \\
\text {-Create on site employment, pay taxes and accrue profits (losses) }\end{array}$ \\
\hline Indirect & Suppliers based off site & $\begin{array}{l}\text { - Involved in delivery of intermediate products and services to airport } \\
\text { firms based on site } \\
\text {-Order various intermediate inputs from various suppliers } \\
\text {-Create off site employment, pay taxes and accrue profits (losses) }\end{array}$ \\
\hline Induced & $\begin{array}{l}\text { All concerned firms and } \\
\text { individuals }\end{array}$ & $\begin{array}{l}\text {-Deliver goods and services to off site suppliers } \\
\text {-Direct and indirect employees spend wages in other sectors } \\
\text {-Create employment, pay taxes and accrue profits (losses) }\end{array}$ \\
\hline Catalytic & $\begin{array}{l}\text { Passenger and freight } \\
\text { transport users }\end{array}$ & $\begin{array}{l}\text {-Expenditure in wider economy } \\
\text { - Travel agent commissions and consumer surpluses } \\
\text {-Create additional employment, payment of taxes and accrual of profits } \\
\text { (losses) }\end{array}$ \\
\hline
\end{tabular}

Source: ICAO (2005)

An input-output analysis along with a general equilibrium model had to be avoided due to limited access to a full breakdown of supplier expenditure and revenues for each branch of economic activity in the region. It was still possible, using an indicative case study based supplier probe in the contrasting island states of Barbados and Trinidad \& Tobago to gain a better understanding of the possible upstream impacts of a given level of air service on GDP and its resulting effect on employment.

A comprehensive passenger survey was designed to firstly capture data pertaining to consumer surpluses which could then be disaggregated by local and foreign carrier for each sampled state, secondly to estimate the correlation between the sector's overall economic contribution and the level of air carrier exportation/importation and finally to measure counterfactually the approximate reduction in demand if local flag carriers were no longer in operation. An accompanying business survey, targeted at regional companies from a range of sectors, was undertaken to establish the extent to which investment plans have been cancelled or delayed by real or perceived deficiencies in intra and extra-regional air services. Published balance of payment and national account data from the Caricom Secretariat and governmental central banks respectively were also employed to examine whether states with home and/or foreign carriers had a higher impact factor in terms of direct foreign exchange as well as direct/indirect GDP and employment contributions. The supplier probe gave a clear indication of direct (on site) and indirect (off site) wages available for expenditure in the wider economy. An estimate of induced impact in the country with and 
without a local carrier could then be computed despite the small sample size of some of the off site companies involved in the production of air transport services ${ }^{5}$.

All relevant data was collected between April 2006 and February 2007, but due to the crosssectional nature of the research undertaken, it was not possible to determine annual variability in the magnitude of the sector's economic contribution. Thus, reliable conclusions can only be drawn for the year 2006. Cost information on wages, government taxes, capital investments and spending on intermediate products was collected from companies in Barbados and Trinidad and Tobago as part of the supplier probe. This type of sensitive data was typically given on the condition that company names remained anonymous.

Based on a cluster sampling technique (Lind et al, 2006), it was estimated that it was possible to quantify and qualify the direct and catalytic impacts for any of the twenty (20) Caricom full and associate member states arriving at a final sample size of seven countries including the Bahamas, Barbados, Dominica, Guyana, Jamaica, St. Lucia and Trinidad \& Tobago. Countries were grouped according to geographical position, national output levels (GDP) and the level of air transport activity ${ }^{6}$. By extension, despite the economic heterogeneity present between the economies of Barbados and Trinidad \& Tobago, it was not feasible to make any regional generalisations from the induced impact results of the supplier probe or indirect results of the national account data.

After a pilot survey was undertaken in Barbados, it was found that variation in passenger expenditure required a minimum sample size of 307 for the passenger survey, and variation in firm size suggested an estimated sample size of 220 for the business survey. In total, 211 business and 327 passenger survey responses were actually gathered between the months of May 2006 and February 2007; the first by means of an on-line survey and the second in the form of a structured interview carried out in the departure areas of seven of the region's main airport terminals. A total of 1,400 on-line surveys were sent to Caricom based businesses with an approximate response rate of $15 \%$. The airport interview was conducted

\footnotetext{
${ }^{5}$ With low standard errors of estimate (z-values) the business population's average total wage bill was estimated to be US $\$ 1.5 \mathrm{mn}$ for Barbadian firms and US\$3.5mn for Trinidadian firms. Subsequently it was found that, using a sample size of $39 \%$ and $29 \%$ of the population of firms in Barbados and Trinidad, sampling error was low, at US\$- $0.15 \mathrm{mn}$ for Barbados and US\$- $0.5 \mathrm{mn}$ for Trinidad.

${ }^{6}$ This was estimated by proxy using the average of total air arrivals and the ratio of air arrivals to arrivals by all modes. Other possible variables for clustering include the percentage of the labour force involved in air transport or the number of air journeys per capita versus GDP per capita.
} 
face-to-face and although some passengers refused to participate, it was still possible to complete as much as $93 \%$ of a predetermined target of 350 responses.

To further validate the use of annual Caricom generalisations, the passenger survey was performed using a method called 'stratified random sampling' (Lind et al, 2006). An approximately equal number of responses were collected from each member state. Out of the seven versions of the survey, four were carried out during the low season (May to November) and three during the high season (December to April); four on busy days and three on relatively quiet days. On an aggregate regional level this ensured seasonal variation could be accounted for by the sample. In addition, all responses were as evenly spread as possible throughout the designated survey day in order to capture variations between peak and off-peak periods, short, medium and long haul destinations, business and leisure passengers, resident and foreign travellers, and regional and foreign carriers.

The passenger survey was modelled on a combination of a typical Civil Aviation Authority (CAA) passenger survey (2004) along with a Caribbean Tourism Organisation (CTO) survey (2004) which is targeted at long-stay tourists travelling by air. This ensured that questions pertaining to air transport, socio-economic, air traveller, air travel choice, and expenditure variables were all taken into account, and not just variables relating to airport activity variables or incoming tourism activity only. The business survey was adapted from an Oxford Economic Forecasting (OEF) survey of UK companies (2006).

\section{RESULTS AND FINDI NGS}

\subsection{DIRECT \& INDIRECT EVI DENCE}

In terms of foreign exchange earnings it is evident that islands with national carriers are more likely to create a greater direct impact than those islands without. This is due to the fact that a greater proportion of total operating costs are internalised and a lower percentage of total revenues are repatriated to foreign countries. Table 4 shows however that in those states which are entirely dependent on foreign carriers, continued growth in overall on-site output ensures a net balance of payment surplus for the sector. This is because the increased output induces more on-site commercial expenditure, employment and use of local products and services as well as providing a source of fiscal revenues. 
Table 4: Balance of payment (BoP) surplus (deficit) against presence (absence) of a local carrier among the sampled Caricom member states (2000)

\begin{tabular}{|c|c|c|}
\hline Caricom Member Country & BoP surplus (deficit) \$USmn & Home based carrier \\
\hline Bahamas & 419.08 & $\overline{\text { Yes }}$ \\
\hline Barbados & 58.78 & No \\
\hline Belize* & 22.09 & Yes \\
\hline Dominica & 1.46 & No \\
\hline Jamaica & 337.17 & Yes \\
\hline St. Lucia & 44.18 & No \\
\hline Trinidad \& Tobago & 97.07 & Yes \\
\hline Aggregated Totals & 979.83 & Yes $=4$, No $=3$ \\
\hline Mean average & 139.97 & - \\
\hline
\end{tabular}

Source: Caricom Trade in Services report (2002)

* Guyana data not available. Belize used as a Caricom substitute.

The two anomalies are shown to be Barbados and Belize. Barbados returned a notably higher direct impact value than the other sampled islands without a national carrier. This could be due to the fact that Trinidadian carrier BWIA and to a lesser extent Antigua and Barbuda based LIAT were using Barbados as a secondary regional hub at that point bringing with it more direct employment and output growth than would normally be the case for an island without an airline based there. Barbados was also the major shareholder of LIAT during this period and despite the continued financial burden of the carrier (as described in Table 1) on the Barbadian taxpayer, contributions towards aeronautical and nonaeronautical revenues as well as payments to airport service providers may have compensated for this deficit ${ }^{7}$. Although Belize has two locally based carriers (Maya and Tropic Air), their limited output of less than 200,000 passengers per annum, along with their insignificant network of international routes suggested low direct contributions to both foreign exchange and internal expenditure.

Jamaica and the Bahamas noted the highest direct impact values. Aside from the fact that they too had national carrier bases, there was evidence that the high number of leisure travellers passing through the islands' major gateways provided a major source of commercial airport revenues and consequently direct foreign exchange earnings. It is unlikely to be a coincidence that of the sampled island states, the Bahamas (18\%) and Jamaica $(11 \%)$ also recorded the highest tourism sector contributions as a ratio of GDP (Tourism Satellite Accounts, 2000-2006). It is these same long-stay visitors that are more likely to buy last minute memorabilia and souvenirs from the airport's retail outlets.

\footnotetext{
${ }^{7}$ This was estimated for the latest available year with regional Balance of Payment data (2000).
} 
Table 5: National account extract for Barbados and Trinidad \& Tobago (2005)

\begin{tabular}{|c|c|c|c|c|}
\hline $\begin{array}{l}\text { Caricom } \\
\text { state }\end{array}$ & Sector & Sector components & Constant Prices (US\$mn) & Full time jobs \\
\hline \multirow[t]{7}{*}{ Barbados } & $\begin{array}{l}\text { Air Transport (Airlines } \\
\text { only) }\end{array}$ & & 3.86 & 255 \\
\hline & $\begin{array}{l}\text { Supporting and } \\
\text { auxiliary services }\end{array}$ & & 35.90 & 2,370 \\
\hline & & Cargo handling & 7.81 & 515 \\
\hline & & Storage and warehousing & 0.77 & 51 \\
\hline & & Airport services and other support & 8.79 & 581 \\
\hline & & $\begin{array}{l}\text { Travel agencies, tour companies } \\
\text { etc. }\end{array}$ & 18.53 & 1,223 \\
\hline & Total Barbados & & $39.76(0.92 \%$ of GDP $)$ & 2,625 \\
\hline \multirow[t]{7}{*}{$\begin{array}{l}\text { Trinidad \& } \\
\text { Tobago }\end{array}$} & $\begin{array}{l}\text { Air Transport (Airlines } \\
\text { only) }\end{array}$ & & 84.33 & 1,507 \\
\hline & $\begin{array}{l}\text { Supporting and } \\
\text { auxiliary services }\end{array}$ & & 158.42 & 2,835 \\
\hline & & Cargo handling & 61.45 & 1,100 \\
\hline & & Storage and warehousing & 5.45 & 98 \\
\hline & & Airport services and other support & 22.80 & 406 \\
\hline & & $\begin{array}{l}\text { Travel agencies, tour companies } \\
\text { etc. }\end{array}$ & 68.72 & 1,231 \\
\hline & $\begin{array}{l}\text { Total Trinidad \& } \\
\text { Tobago }\end{array}$ & & $242.75(1.78 \%$ of GDP) & 4,342 \\
\hline
\end{tabular}

Source: Barbados and Trinidad \& Tobago statistical service

Note: Disaggregated employment values were estimated iteratively using ratios between GAV's of different sector components

Expenditure and employment data pertaining to on and off site air transport activity was available for Trinidad \& Tobago and Barbados through their national account data, which was last performed for a limited range of sectors in the year 2005. Although not an exhaustive list, a fair indication of indirect activity as a ratio to direct, on site activity could be assembled and commented upon (See Table 5). Under the sub-heading 'supporting and ancillary air transport services', activities relating to off site cargo handling, storage and warehousing, ground handling administration and travel agency/tour company interests were included. Off site output in Barbados was around ten times more significant than on site output. This was only achievable because of the large contribution made by travel agents and tour operators, reflecting a higher level of visitor activity taking place outside the airport vicinity in comparison to Trinidad. Trinidad not only had a lower indirect to direct ratio of around two but also had a relatively low travel agency and tour company contribution to total indirect output levels. This shows that Barbados' lack of a national carrier was partially compensated indirectly through greater levels of visitor related output off site. On the other hand the situation in Trinidad implied a heavier reliance on the direct contributions of home carrier BWIA and the continued operation of its Piarco base given its comparatively low level of off site tourist activity.

For Trinidad \& Tobago, the direct impact value of US\$84 million in the national account extract was broadly consistent with the Balance of Payment value of \$US97 million as shown 
by Table 4 adding validity and reliability to the secondary data sources. Having a flag carrier based in Trinidad also led to investment in on site freight, maintenance and technical facilities. Trinidad's reputation for technical expertise also led Caribbean Star to directly invest in a small crew and maintenance facility at Piarco in 2005, which was later incorporated into the LIAT entity after the two carriers merged in 2007. While Barbados was a sub-regional hub for LIAT and BWIA, not having any aircraft based at Grantley Adams inevitably explained the lower levels of employment and expenditure recorded there. The national account direct impact value is also much more modest for Barbados than it is in the Balance of Payment table. The inference here is that the continued blanket subsidy for poor performing LIAT by the Barbados government between 2001 and 2005 may have resulted in a reduced direct impact contribution. This is especially the case given large sums of this subsidy was invested, not in expanding activities in Barbados, but in furthering LIAT's presence as the home carrier of Antigua and Barbuda. Barbados therefore did not experience the assumed direct impact benefits that Trinidad \& Tobago enjoyed as a result of providing financial support to a local carrier.

\subsection{INDUCED \& CATALYTIC EVI DENCE}

\subsubsection{SUPPLIER PROBE}

Due to expenditure leakages in the form of capital or infrastructure investment and the associated importation of intellectual property, construction material and technology, the gross on site and off site expenditures as noted in Tables 6(a) and 6(b) have to be netted before being inputted into the national accounts as additional value creation for an economy (See Table 5). Owing to its wider ranging manufacturing base however, the absolute difference between gross expenditure and net value added is not as marked in Trinidad as it is for Barbados. Despite the leakages, a sizeable quantity of expenditure clearly flows down the air transport supply chains both in Trinidad and Barbados. The presence of a home carrier in the case of Trinidad clearly contributed to the fact that more employee income was generated by Piarco than it was by Grantley Adams, where a greater proportion of airline expenditure in the form of employee wages was repatriated back to the carrier's country of origin. Using the representative supplier probe sample, an estimation of total population income generation was derived from the computed average income per organisation. For Trinidad this equated to a total income generation of around US\$150 million for the year 2006 where as in Barbados it was valued at US\$48.86 million. Net of any 
household leakages in the form of product and service imports, these values form an estimation of the induced impact of the sector to Trinidad and Barbados in extra internal spending and savings.

Table 6(a): Barbados international airport supplier probe

\begin{tabular}{|c|c|c|c|c|c|c|c|c|c|c|}
\hline \multirow{2}{*}{$\begin{array}{c}\text { Account item } \\
\text { (US\$mn) }\end{array}$} & \multicolumn{2}{|c|}{ Airlines $(n=9)$} & \multicolumn{2}{|c|}{$\begin{array}{c}\text { Airport authority } \\
(\mathrm{n}=1)\end{array}$} & \multicolumn{2}{|c|}{$\begin{array}{l}\text { Ground handling } \\
\text { agents }(n=2)\end{array}$} & \multicolumn{2}{|c|}{$\begin{array}{c}\text { Travel agency } \\
(n=1)\end{array}$} & \multicolumn{2}{|c|}{$\begin{array}{c}\text { Catering supp. } \\
(n=1)\end{array}$} \\
\hline & $\begin{array}{l}\text { On } \\
\text { site }\end{array}$ & $\begin{array}{l}\text { Off } \\
\text { site }\end{array}$ & On site & Off site & On site & Off site & $\begin{array}{l}\text { On } \\
\text { site }\end{array}$ & $\begin{array}{l}\text { Off } \\
\text { site }\end{array}$ & $\begin{array}{l}\text { On } \\
\text { site }\end{array}$ & $\begin{array}{l}\text { Off } \\
\text { site }\end{array}$ \\
\hline $\begin{array}{l}\text { Spend on inter. } \\
\text { goods }\end{array}$ & 70 & 12 & 12 & 0 & 2 & 1 & 0 & 3 & 0 & 2 \\
\hline $\begin{array}{l}\text { Spend. on } \\
\text { investment }\end{array}$ & 5 & 8 & 81 & 0 & 2 & 1 & 0 & 7 & 1 & 0 \\
\hline Wages/Salaries & 3 & 2 & 5 & 0 & 6 & 0.2 & 0 & 2 & 0.3 & 0.6 \\
\hline Government taxes & 13 & 3 & 7 & 0 & 1 & 0.5 & 0 & 1 & 0.2 & 0.3 \\
\hline Total expenditure & 91 & 25 & 105 & 0 & 11 & 2.7 & 0 & 13 & 1.5 & 2.9 \\
\hline Jobs created & 126 & 84 & 211 & 0 & 174 & 15 & 0 & 78 & 12 & 22 \\
\hline
\end{tabular}

Note: All passenger and freight airlines with base, secondary hub or regional offices were included in sample

Table 6(b): Trinidad international airport supplier probe

\begin{tabular}{ccccccccccc}
\hline $\begin{array}{c}\text { Account item } \\
\text { (US } \$ \mathrm{mn})\end{array}$ & \multicolumn{2}{c}{ Airlines $(\mathrm{n}=9)$} & \multicolumn{2}{c}{$\begin{array}{c}\text { Airport authority } \\
(\mathrm{n}=1)\end{array}$} & $\begin{array}{c}\text { Ground handling } \\
\text { agents }(\mathrm{n}=2)\end{array}$ & $\begin{array}{c}\text { Travel agency } \\
(\mathrm{n}=1)\end{array}$ & \multicolumn{2}{c}{$\begin{array}{c}\text { Clothing supplier } \\
(\mathrm{n}=1)\end{array}$} \\
\hline Department location & $\begin{array}{c}\text { On } \\
\text { site }\end{array}$ & $\begin{array}{c}\text { Off } \\
\text { site }\end{array}$ & On site & Off site & On site & Off site & On site & $\begin{array}{c}\text { Off } \\
\text { site }\end{array}$ & On site & Off site \\
$\begin{array}{c}\text { Spend on inter. } \\
\text { goods }\end{array}$ & 132 & 23 & 51 & 0 & 5 & 4 & 0 & 3 & 5 & 1 \\
$\begin{array}{c}\text { Spend. on } \\
\text { investment }\end{array}$ & 12 & 31 & 28 & 0 & 1 & 2 & 0 & 2 & 7 & 0 \\
Wages/Salaries & 14 & 15 & 4 & 0 & 4 & 0.5 & 0 & 2.5 & 0.2 & 1.8 \\
Government taxes & 25 & 9 & 13 & 0 & 1 & 1 & 0 & 1 & 2 & 0.2 \\
Total expenditure & 183 & 78 & 79 & 0 & 11 & 7.5 & 0 & 8.5 & 14.2 & 3 \\
Jobs created & 682 & 738 & 160 & 0 & 214 & 22 & 0 & 95 & 6 & 56 \\
\hline
\end{tabular}

Note: All passenger and freight airlines with base, secondary hub or regional offices were included in sample

In terms of induced income generation, it would appear that Trinidad has benefit from supporting a national carrier. However, it must be noted that, due to the limited contribution of other sectors in Barbados relative to other sectors in Trinidad \& Tobago, net contribution to GDP was actually $18 \%$ higher for Barbados. The macroeconomic impact of the presence of a home carrier can therefore be moderated or intensified depending on a nation's level of sector diversification. 


\subsubsection{CONSUMER SURPLUS}

Value placed on a journey, net of ticket cost is called consumer surplus. When every individual in a market is sampled, this measures the portion of a downward sloping demand curve that would have paid more than the price they were actually offered. This value is frequently converted into extra expenditure at a destination or further business travel which otherwise would not have taken place if air carriers were to capture every individual's consumer value. For this reason it is inextricably linked with the catalytic or spin-off effects of the provision of air services.

Table 7: Net consumer surplus segmented into type of resident, carrier and route

\begin{tabular}{lr}
\hline Explanatory variable & Net consumer surplus per passenger (US\$) \\
\hline Caricom resident $(n=219)$ & 108.26 \\
Foreign resident $(n=259)$ & 176.87 \\
\hline Caricom average $(n=478)$ & 144.31 \\
\hline Caricom carrier $(n=215)$ & 98.39 \\
Foreign carrier $(n=187)$ & 149.36 \\
Caricom and foreign carrier combined $(n=76)$ & 261.79 \\
\hline Caricom average $(n=478)$ & 144.31 \\
\hline Intra-regional routes $(n=121)$ & 81.96 \\
Extra-regional routes $(n=357)$ & 206.66 \\
\hline Caricom average $(n=478)$ & 144.31 \\
\hline
\end{tabular}

Source: Author's survey

Note: $\mathrm{n}$ is greater than the total number of survey responses. This is because some responses consisted of groups or families covering multiple air fares. Sub-fields may not work out into the exact Caricom average due to rounding errors

On average, respondents of Caricom residence placed less additional value onto their air tickets than foreign residents did (See Table 7). This could be explained by the respective differences in disposable incomes and by the higher airfares being charged to local travellers. As distances are much lower for intra-regional routes, average consumer surplus appears to be disproportionately low when compared to extra-regional routes. This could be exacerbated by the fact that regional carriers typically present the only option for Caricom residents travelling between intra-regional points giving local carriers the opportunity to exercise greater fare flexibility. Conversely, respondents making interline connections with both a Caricom and a foreign carrier gained the highest amount of consumer surplus. For a passenger to go through the inconvenience of purchasing multiple fares and connection waiting times, a high level of demand inelasticity is assumed. The practise of interlining may be a more viable alternative in the US, for example, where there is often a critical mass of frequencies and airline co-operation. This level of convenience often does not exist in the Caribbean, adding weight to the idea that passengers interlining in the Caribbean place high 
values on their ability to do so. It further suggests that catalytic impact through higher levels of consumer surplus can be maximised if foreign carriers are allowed to operate freely into the sampled states, creating more opportunities for highly valued feeder services provided by local carriers to islands which do not currently benefit from trunk route services.

\subsubsection{FACILITATION OF EXPENDITURE}

Although invariably there are competing claims within an economy as to which sector(s) are to be credited with incoming visitor expenditure, it is important to consider the possible magnitude of expenditure facilitation when attempting to undertake an extended approach to the sector's socio-economic impact. It can be assumed therefore that non-apportioned visitor expenditure as estimated in this paper equates to the maximum possible contribution or upper impact limit of net airport user expenditures in the wider economy ${ }^{8}$.

As predicted, the aggregate Caricom passenger survey results showed a net surplus of air transport user expenditure (Figure 2). This was supported by an estimated incoming traffic ratio of $65 \%$. Moreover, outgoing local respondents tended to spend less per night than incoming foreign visitors. This served to increase the net incoming expenditure result further. Despite a high Caricom average, which was estimated at over \$US400 million, disaggregated results show a high variability among the sampled states. Trinidad \& Tobago was the only sampled state to return a net deficit, but due to the relatively small contribution of tourism spend to GDP (PPP), this deficit affected GDP by less than $1 \%$. On the other hand, total visitor spend in St. Lucia was below average in absolute terms but this impact equated to approximately $46 \%$ of GDP (2006). This may be explained by the relatively high importance of visitor expenditure to the small island's economy when compared to the larger, diversified economies of Trinidad \& Tobago and Jamaica. However sampling error may have also contributed to what appears to be an overstated estimate. Only $14 \%$ of responses gathered in St. Lucia were local residents but according to St. Lucia airport authority statistics for the year 2006, as much as 34\% of travellers were outgoing St. Lucian residents (SLASPA, 2007).

\footnotetext{
${ }^{8}$ Note however that marginal contributions in terms of crew and general aviation visitor spend have been included in catalytic impact studies at other airports (e.g. Los Angeles, USA) yet they have not in this paper.
} 
Figure 2: Net incoming visitor expenditure and \% contribution to GDP

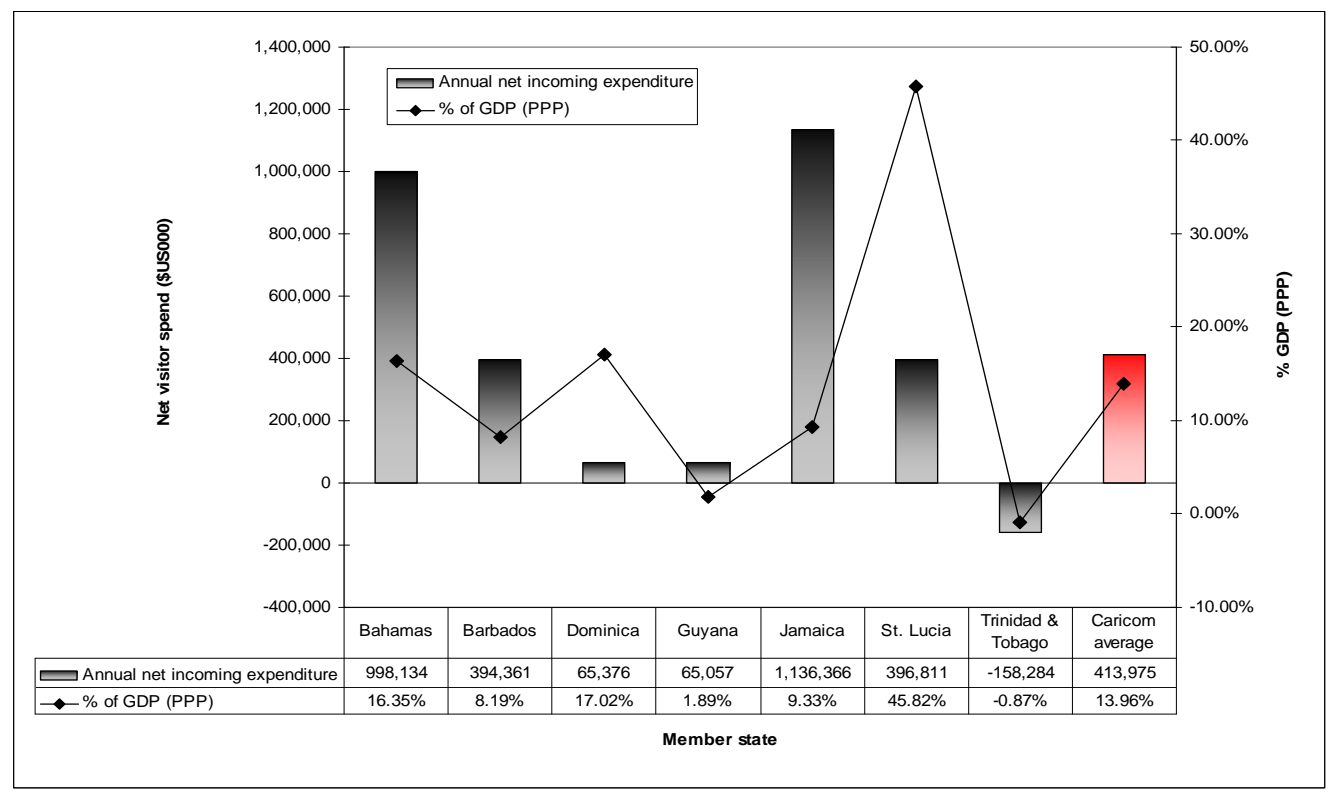

Note: To arrive at annual net impact estimates, a scaling factor was derived from the ratio between the sample number of observations and the net incoming expenditure they produced. A multiple was then applied using net yearly incoming passenger arrivals to arrive at an annual approximation for the year 2006.

The presence of Air Jamaica in Jamaica and BahamasAir in the Bahamas does not seem to have had a modifying effect on the amount of net incoming expenditure. In fact, although secondary airports like Freeport (Grand Bahama) and Marsh Harbour (Abaco island) have benefit from an increasing number of direct flight in recent years, the role of BahamasAir in providing domestic feeder services between Nassau and the outer islands clearly facilitated extra catalytic expenditure and as well as improved social cohesion between the islands. Trinidad \& Tobago has seen a dearth of medium and long haul flights provided by foreign carriers when compared to other Caricom states. A lack of tourism infrastructure, increasing local crime rates in Port of Spain and the continued presence of BWIA may have been factors causing the missed incoming visitor opportunities which have been provided by foreign US and European carriers in the Bahamas, Jamaica and Barbados.

The case of BWIA in Trinidad \& Tobago appears to imply that there is a trade-off to be made in order to ensure the maximum net macroeconomic impact accrues to the national economy. If incoming visitor traffic has been suppressed due in part to the lack of foreign carriers offering routes into Trinidad \& Tobago, then this detriment appears to have been compensated by the direct and indirect output and employment created by the presence of a domiciled flag carrier. The existence of high multipliers (see Table 8) in some of the other 
sampled states however, hint at more substantial macroeconomic gains from a greater focus on increasing incoming passenger expenditure in the wider economy.

\subsubsection{LEVEL OF CARRIER IMPORTATION, EXPORTATION AND DOMESTIC CONSUMPTION}

The survey results suggest that Caricom travellers, when the option is available to do so, usually choose to travel with regional carriers as opposed to foreign carriers and vice versa reflected by the fact that only $35 \%$ of respondents chose to import air services from foreign carriers. On international routes with choice, local travellers generally continued to choose to travel with regional carriers despite the fact that the survey results generally suggest higher fares and lower frequencies than those offered by foreign carriers. It may be the custom or the norm for Caricom customers to avoid importing air services. Loyalty programmes offered by Air Jamaica, BWIA and LIAT may have prevented carrier switching to a certain extent in addition to the idea of familiarity with carrier customs and practises as sometimes being a social factor which can override purely economic considerations (Yoo \& Ashford, 2007).

Of the 478 sampled airfares, only $16 \%$ covered respondents making connections in the region. Thus, given the majority of travel to and from the region is direct and the lion's share of net incoming expenditure is provided by foreign visitors travelling on foreign carriers, it is important to point out that, at least in the short to medium term, foreign carriers appear to play a greater role in facilitating incoming catalytic spending than do the region's home carriers. By extension, if feeder services in the region are intensified, there is no reason to believe that local carrier contributions to net visitor spend cannot be enhanced.

\subsubsection{REDUCTI ON IN DEMAND AND JOB DISPLACEMENT IN ABSENCE OF LOCAL CARRIERS}

It was possible to estimate counterfactually, using the percentage of respondents who stated that demand would decrease as a result of a reduction to three important air transport service aspects, the amount of full time equivalent jobs that would be lost as a result of such a reduction in output. To discover if long run levels of output would actually reduce in the absence of local carriers however, respondents were also asked if they 
believed the three service indicators ${ }^{9}$ would improve or deteriorate if the loss making local carriers ceased operations. The aggregate results are presented in Figure 3.

Figure 3: Possible impact on output levels of a given selection of service indicators in the absence of regional carriers

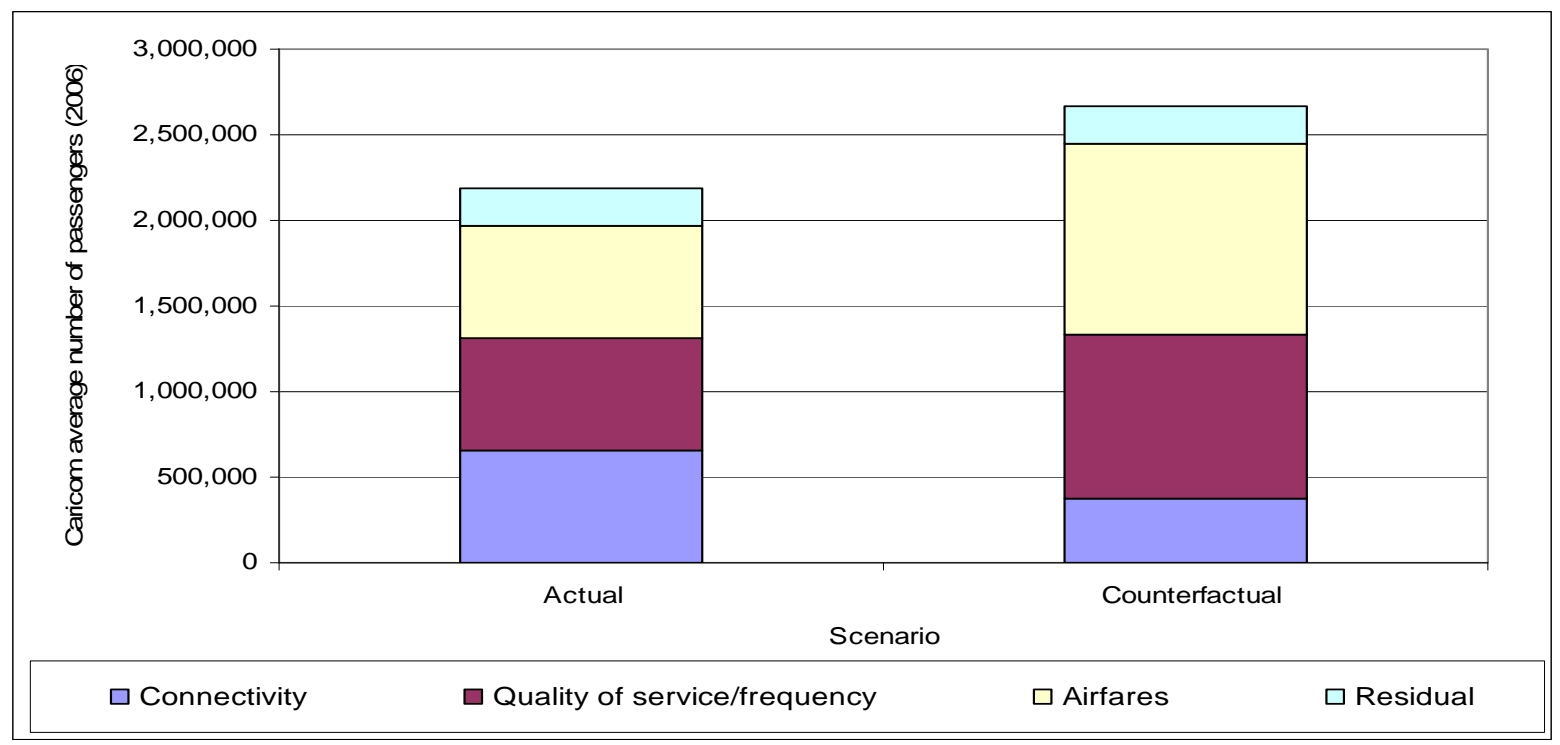

Source: Caricom passenger survey, author's calculations

With an assumed residual of $10 \%$, the average output level for the sampled states of $2,188,000$ passengers was believed to be determined by the three endogenous variables equally. Ability to make connections either by interlining or onlining for instance, was thought to produce $30 \%$ of total output for 2006 . This output was then multiplied by the ratio of respondents who agreed or strongly agreed that demand within, to and from the region would decrease if there was a reduction in air connectivity and again by the ratio of respondents stating that connectivity would reduce in the absence of local carriers. Consequently, an adjusted counterfactual ratio for connectivity was estimated at $13 \%$, giving an output reduction of $17 \%$. This iterative process was repeated for frequency/quality of service and airfares but unlike the first service indicator, respondents supported the hypothesis that output would actually increase as a result of foreign carrier airfare reductions and quality of service improvements in the absence of local carriers. Overall, the passengers surveyed felt that aggregate output would increase by $12 \%$ or by 263,360 passengers in the absence of local carriers (Figure 3).

\footnotetext{
${ }^{9}$ The three air transport related factors which were declared to be most influential on aggregate demand in the region were the level of connectivity, the level of airfares and the level of frequency/quality of service.
} 
While the validity of the results is based on the subjective views of the survey's passenger respondents, it must not be overlooked that stated travel preferences and factors influencing decisions to travel are in themselves highly subjective. Thus the opinions of the traveller were considered to be one of the most appropriate methods by which to examine counterfactually what would happen to demand when subjected to the impairments described in Figure 3.

In the scenario where the absence of local carriers does lead to a reduction in output and related employment, the ability of an individual sampled economy to incorporate the displaced workers is dependent firstly upon its magnitude and secondly upon its sector diversification as measured by the number of industries directly and indirectly dependent upon an economy's air transport industry. If output is said to decrease by $10 \%$ as a result of a reduction in local carrier services, on average, it is estimated that on site companies and off site suppliers would have to downsize by approximately 164 full-time equivalent jobs. In turn, a further 72 jobs could be lost in the wider economy if displaced workers could not find jobs in other sectors with equivalent wage rates.

\subsubsection{INVESTMENT PLANS AFFECTED BY PERCEIVED LOCAL CARRIER DEFICIENCIES}

Previous studies have recorded the relative importance of good air transport links when making decisions regarding new capital investments (OEF, 2006). A study commissioned by the Department for Transport (2004) also suggests that availability and efficiency of routes and perceived and actual air connectivity between states are the most relevant factors in determining the role of air transport in facilitating international business activity and investment. Overall, $27 \%$ of Caricom business respondents cited that perceived or actual deficiencies in air transport had affected their decisions to invest in other countries (Figure 4). Given that approximately $80 \%$ of respondents chose or had to travel by one of the region's flag carriers; this implies that the majority of these complaints were related to air services provided by regional carriers, LIAT, Caribbean Star, BWIA, Air Jamaica and BahamasAir. Around $57 \%$ of business investments that were said to be hindered by air transport cited a lack of direct flights, high freight rates/airfares, low capacity, low frequency and an unreliable and inconsistent service as the main reasons why investments were affected. Four respondents went as far as to say that the region's loss making carriers actually damage the region's reputation as a suitable place to do business and that, in part, 
perceived deficiencies had actually prevented foreign companies from investing in the region.

Figure 4: Percentage of investment decisions that were effected by perceived air transport deficiencies

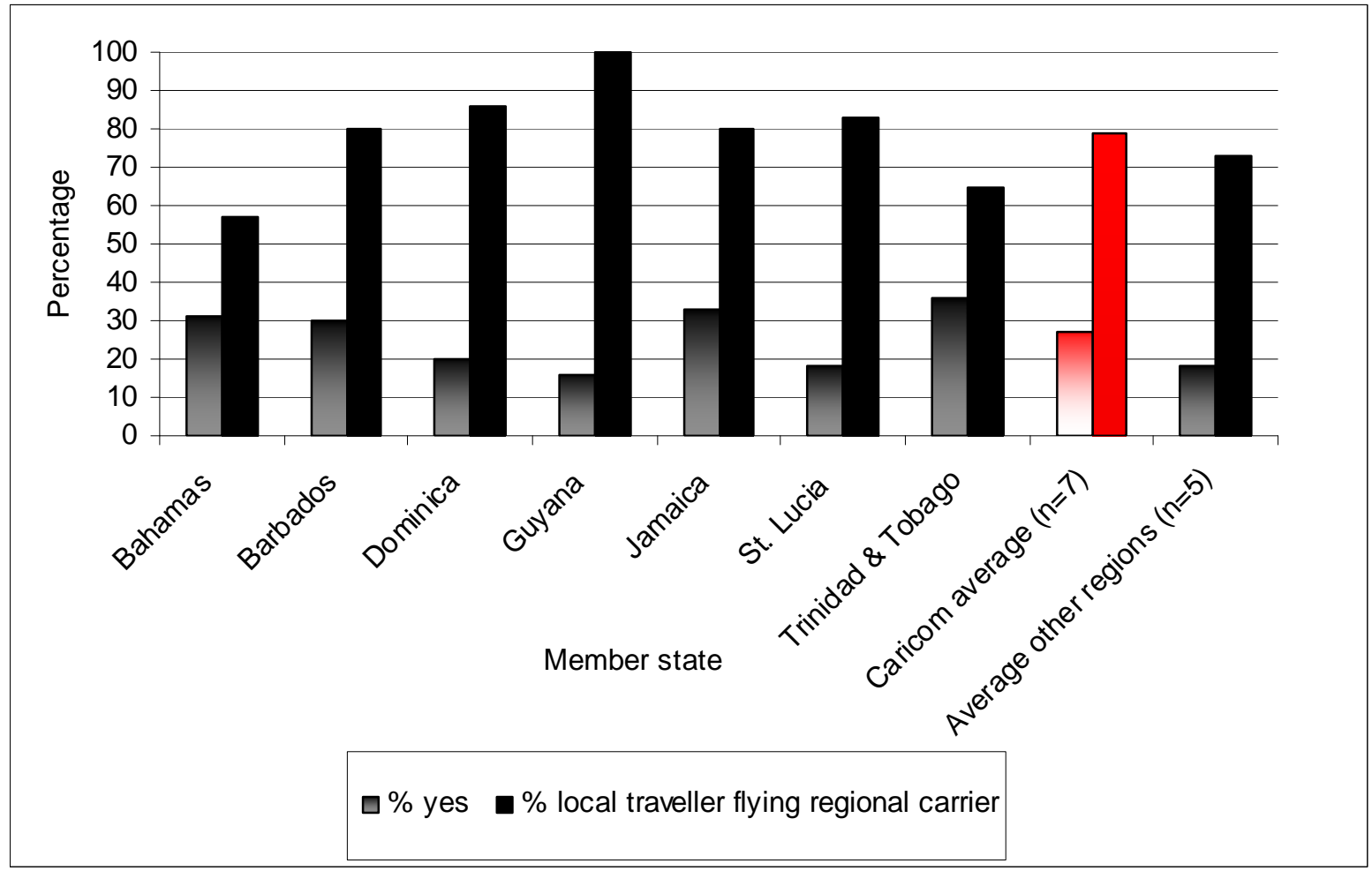

Source: Business survey, OEF (2006)

Some of the responses from the smaller states in the region namely Dominica and St. Lucia and the sample's peripheral state, Guyana, did not cite, as frequently, the air transport sector as a hindrance to business investment. This may have been due firstly to a lower absolute level of investment activity and second to a higher tolerance level for the region's carriers whose routes to their countries are actually subsidised by other member states. A global sample of five countries in another study (OEF, 2006) returned a lower ratio of 'yes' responses for the investment question to the number of resident travellers choosing to fly with national carriers (OAG, 2007) than the ratio shown for the sampled Caricom countries. This indicates perhaps that there is a greater correlation between usage of national carriers and hindrance of business activity than for countries in other regions. 


\subsubsection{OVERALL IMPACT COMPARISON BETWEEN MEMBER STATES}

Estimates of net visitor spend facilitated by the region's air transport sector represent values approaching their upper limit. Accordingly, the omission of indirect and induced impact values for five of the sampled member states serves to reduce the risk of overstating the sector's overall impact magnitude. Despite the omissions, a clear pattern emerges from both the disaggregate expenditure and employment results as presented in Figure 5. While none of the sample airports processed more than four million passengers in 2006 , off-site activity was still found to be thriving, especially within the travel, tourism, hospitality and ancillary service sectors. Invariably those states which experienced large numbers of long-stay visitor traffic, also proved to be the same states that enjoyed high impact multipliers both in terms of expenditure and employment. This occurred to varying degrees in Jamaica, the Bahamas, Barbados Dominica and St. Lucia. The multiplier in Jamaica and the Bahamas was moderate in comparison to Barbados, St. Lucia and Dominica. This largely agrees with the finding that the presence of domiciled carriers can produce high direct, on-site impact values and employment even if carriers are subsidised and loss making ${ }^{10}$. The resulting catalytic to direct impact ratio was therefore dampened in the case of Jamaica and the Bahamas. Nevertheless, it appears that, in countries that are completely at liberty to attract further extra-regional visitor spend, facilitated by lower priced foreign carriers (See Table 7), multiplier values are most significant. Without the direct market presence of regional carriers, St. Lucia, Dominica and Barbados are free to attract extra services from Europe and North America without having to worry about the economic implications for competing local carriers. Jamaica, the Bahamas and Trinidad \& Tobago do not seem to exercise the same amount of freedom although in practise more Estimated direct, indirect, induced and catalytic impact of the air transport sector for the selected Caricom member states flexible approaches in the Bahamas and Jamaica have helped to reap the desired effect in terms of foreign carrier facilitated tourism spend $(83 \%$ and $70 \%$ of direct extra-regional services respectively in 2006).

\footnotetext{
${ }^{10}$ It was not possible however to compare the long-term effect of local carrier losses and continued subsidy due to the crosssectional nature of the study.
} 
Figure 5: Estimated direct, indirect, induced and catalytic impact of the air transport sector for the selected Caricom member states
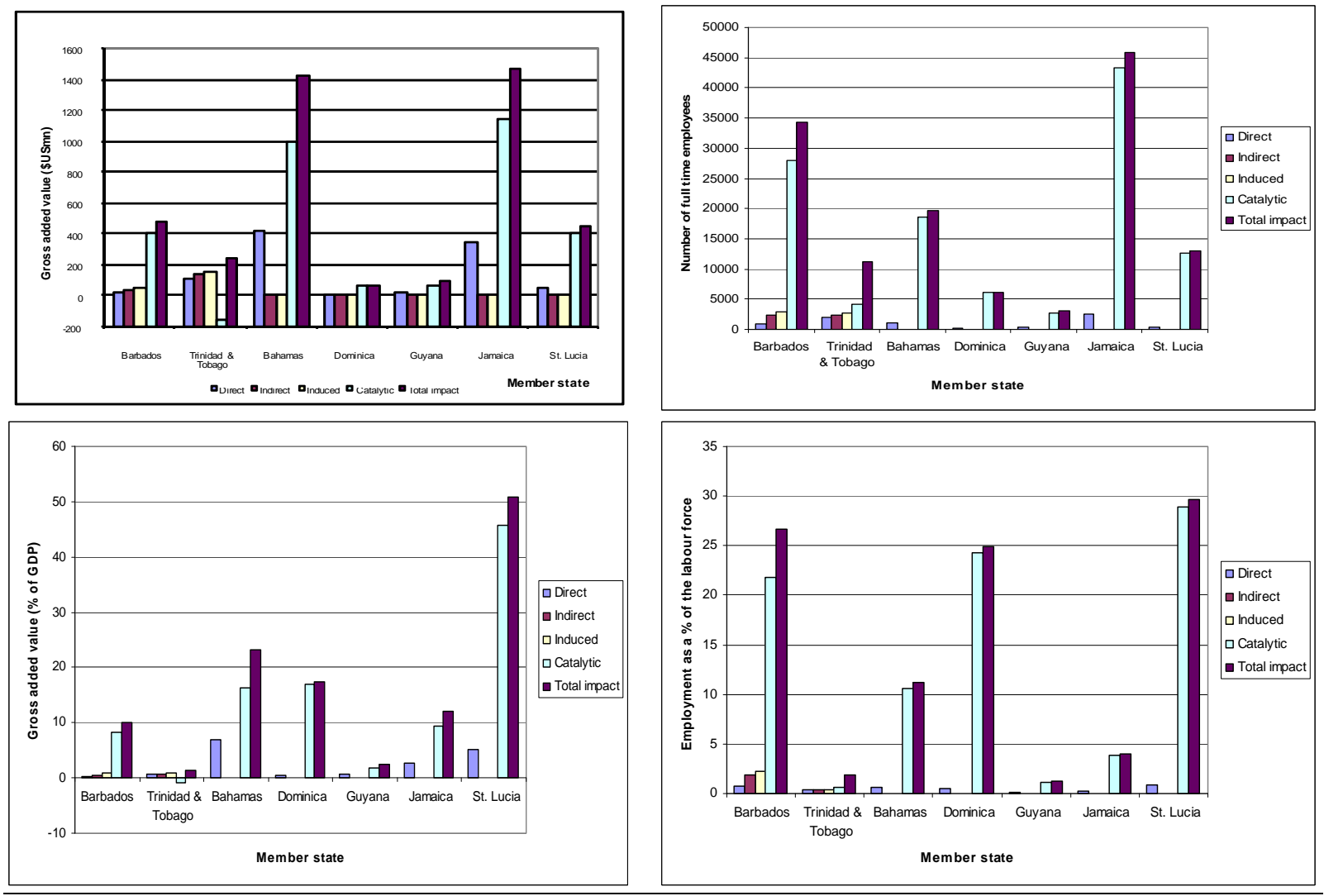

Sources: Author, Caricom member state national account data (2005), Caricom Balance of Payment data (2002)

Notes: Consumer surplus values (catalytic) evident from the Passenger Survey results are not included in the annual statements. For direct impact GAV estimation, Belize was used as a substitute for Guyana due to the omission of Guyana in the BoP data. GAV Multiplier: Barbados $=\mathbf{3 5 . 9 8}$, Trinidad \& Tobago $=\mathbf{2 . 0 8}($ Bahamas $=3.38$, Dominica $=45.78$, Guyana $=$ 3.94, Jamaica $=4.37$, St. Lucia $=9.98$ )

The case of Dominica shows that although absolute values are relatively marginal, when estimated in terms of percentage of GDP (PPP) it becomes clear that net economic impact is more significant in small islands with low levels of sector diversity and internal growth. The priority for states like Dominica must be to balance the need for intra-regional connectivity which appears to be better provided by regional carriers with the need for additional extraregional visitor spend which has hitherto been facilitated mainly by foreign carriers. Furthering efforts to improve interlining capability and marketing Dominica as a suitably priced alternative destination for intra-regional passengers may encourage further joint participation from both local and foreign carriers.

As the only member state to experience a net deficit in catalytic expenditure, Trinidad \& Tobago is currently more dependent on its role as a regional centre for technical and 
manufacturing expertise rather than incoming visitor expenditure. Of all the sampled states, it was noted that Trinidad \& Tobago enjoyed the highest number of contributions from ancillary service providers driven in part by the presence of local carrier BWIA and also by the record levels of economic growth currently benefiting the manufacturing based island. Consequently, despite direct and indirect activity more than compensating for the deficit in catalytic expenditure, overall impact in absolute and percentage terms was insignificant. Catalytic contributions can be further enhanced if Trinidad \& Tobago can manage to secure additional low cost and more convenient air services. A high percentage of business travellers also cited that air transport has at one time or another hindered their investment opportunities. As the Trinidad economy expands, it is critical that its reputation as a competitive place to do business is not affected by poor local carrier service levels. Tobago, as Trinidad's tourism based sister island, would also benefit from additional direct foreign carrier services in addition to the important connecting service already provided by Caribbean Airlines through Port of Spain.

\section{CONCLUSION}

The overall impact of the sector was shown to be related to the magnitude of a state's spillover effects, which itself is invariably linked to aggregate levels of incoming passenger throughput and the additional expenditure which this creates. When mixed or foreign carrier dominant markets were assessed, it was found that rates of capacity have increased more rapidly than on local markets which have been dominated by regional carriers. This suggests that although having a flag carrier base is advantageous in terms of its direct, on-site impact, the sector's wider role in facilitating and promoting further tourism and business activity overwhelms the direct impact variability shown between states that benefit from a local carrier and those that do not. In fact, of the three sample states with the highest overall gross added value estimates (as a percentage of GDP): St. Lucia, Bahamas and Barbados, only the Bahamas, with its notable network of domestic and international routes provided by flag carrier Bahamasair returned a significant on-site to total activity ratio.

However, it has also been observed that national flag carriers do have a macroeconomic role to play although their value creation has often been overestimated by previously studies limited in scope (e.g. Clarke et al, 2005). The survey results suggest current low levels of air carrier importation. Carrier loyalty schemes as well as carrier familiarity with local cultural 
practises must not be overlooked purely because it is difficult to quantify the macroeconomic impact of such preferences. In the counterfactual analysis passengers also eluded to the role of the region's flag carriers in sustaining island connectivity although when traded-off against possible decreases in air fares and improvements in quality of service in the absence of such carriers, overall predicted output levels was estimated to increase. In line with the findings of Bruning (1997), the counterfactual results imply that perhaps further foreign carrier entry on traditionally local routes and vice versa may lead to the desired competitive efficiency effects that would in turn lead to the higher levels of carrier switching alluded to in that study (1997).

Local business travellers, who mainly travel on the region's national carriers, pointed towards high freight rates/airfares, a low number of direct flights, few and inconvenient frequencies and schedules, and under-capacity in terms of seats and cargo as the main reasons why investment plans were hindered. Consumer surpluses were buoyant for both local and foreign carriers although significantly reduced for both the region's flag carriers and for local travellers, who were found to pay disproportionately high fares for some of the regions short sector routes (Figure 1 ).

The supplier probe in Trinidad \& Tobago and Barbados highlighted BWIA's role in facilitating income expenditure in the wider economy with more modest results for Barbados in the absence of a domiciled carrier. It suggested Barbados' induced impact could be further enhanced if periodical subsidies to LIAT translated into an expansion of LIAT activity at Grantley Adams airport. Differences in absolute levels of GDP however resulted in a greater relative income contribution in Barbados than in Trinidad, denoting the moderating effect exogenous factors can have on the magnitude of the sector's economic impact.

\section{References}

- Airports Council International Europe (2004), The social and economic impact of airports in Europe.

- Air Transport Action Group (2005), The economic and social benefits of air transport, Final Report, May 2005.

- Barrett, SD. (2006), Commercialising a national airline - the Aer Lingus case study, Journal of Air Transport Management, 12, 159-167.

- Bruning, ER. (1997), Country of origin, national loyalty and product choice: The case of international air travel, International Marketing Review, 14, 59-74.

- Caribbean Development Bank (CDB), On-line project information, available from:

- http://www.caribank.org. 
- Caribbean Region Sustainable Tourism Development Programme (2007), A proposed policy regime for ensuring the sustainability of the Caribbean's air transport services sector, Barbados, August.

- CARICOM Secretariat (2002), Trade in Services report 1990-2000, Statistics sub-programme, July.

- Chouthi, S. (2006), LIAT moves from red to stable, Trinidad Guardian, $8^{\text {th }}$ July

- Civil Aviation Authority (2004), CAA passenger survey report 2004: Survey of passengers at Gatwick, Heathrow, Luton, Manchester \& Stansted Airports, Economic Regulation Group.

- Civil Aviation Authority (1994), Economic impact of new air services: A study of new long haul services at UK regional airports, CAP 638, November 1994.

- Clarke, J-P, Miller, B, Riedel, R, Pamidimukkala, P, Raimondi, M. (2005), Estimation of the economic benefit of Air Jamaica to Jamaica between 1995 and 2004, Report No. ICAT-2005-3, MIT International Centre for Air Transportation, Massachusetts Institute of Technology, July.

- Department for Transport (2004), The importance of transport in business location decisions, Napier University, J anuary.

- Doganis, R. (2003), Flying off course: The economics of international airlines ( $3^{\text {rd }}$ Edition), London: Routledge Taylor \& Francis Group.

- International Civil Aviation Organisation, (2005). Caribbean/South American regional traffic forecasts 2004-2015. Doc. 9878. Report by the CAR/SAM Traffic Forecasting Group, Lima, Peru.

- International Civil Aviation Organisation (2005), Economic contribution of civil aviation, Circular 292-AT/124, November.

- International Civil Aviation Organisation (ICAO), On-line flight stage statistics facility, available from: http://icaodata.com.

- Lind, D.A, Marchal, W.G, \& Wathen, S.A. (2005), Statistical techniques in business and economics (12 ${ }^{\text {th }}$ edition), McGraw Hill publishers.

- Madjd-Sadjadi, Z. (2005), Comments on the recent MIT economic benefit study, Jamaica Observer, August.

- Montalvo, J.G. (1998), A methodological proposal to analyse the economic impact of airports, International Journal of Transport Economics, 25 (2), 181-203.

- O'Donoghue, M. (1969), A cost- benefit evaluation of I rish airlines, Journal of the Statistical and Social Inquiry Society of I reland, 1968/1969 22, 155-180.

- Official Airline Guide (2007), Subscribed global schedules iNET data.

- Oxford Economic Forecasting (2006), The economic contribution of the aviation industry in the UK, Oxford, October.

- Pagliari, R. (2003), The impact of airline franchising on air service provision in the Highlands and I slands of Scotland, Journal of Transport Geography, 11, 117-129.

- Pearce, B. (2005), New evidence on the wider economic benefits of air transport, International Air Transport Association (IATA).

- Raguraman, K. (1997), Airlines as instruments for nation building and national identity: case study of Malaysia and Singapore, J ournal of Transport Geography, 5, 239-256.

- St. Lucia Air and Sea Ports Authority (SLASPA). On-line air traffic statistics, available from: http://www.slaspa.com/c_reports.php.

- World Bank Document, (2006), Caribbean air transport: Strategic options for improved services and sector performance, Finance, Private Sector and Infrastructure Department, Washington, DC.

- World Travel \& Tourism Council (2005), Travel \& tourism: Sewing the seeds of growth, Travel and tourism research, Caribbean region Tourism Satellite Accounts.

- Yoo, KE, Ashford, N. (2007), Carrier choices of air passengers in Pacific Rim: Using comparative analysis and complementary interpretation of revealed preference and stated preference data, Transportation Research Board, 1652, 1-7. 